\title{
Analysis of School Policies in Implementing Learning Activities as Response to The Covid-19 Pandemic
}

\author{
Ainul Hayat* \\ Public Administration \\ Brawijaya University \\ Malang, Indonesia \\ *ainulhayat@brawijaya.ac.id
}

\begin{abstract}
This study aims to analyse the school policies in implementing learning activities as a response to the Covid-19 pandemic. This study was located at SMK Negeri 2 Malang that one of the public schools in Malang. The Covid-19 pandemic has changed the paradigm of learning activities at SMK Negeri 2 Malang. E-Learning becomes the main choice in implementing learning during a pandemic because E-learning activities can be held anytime and anywhere. E-learning by using LMS (Learning Management System) at SMK Negeri 2 Malang is the principal's policy where it is implemented to standardize distance learning activities. The policy is supported by school management with the following reasons: a) the variety of using media in learning activities, b) student's complaints about the variety of media used by teachers, c) difficulties in controlling the implementation of online learning. The development of e-modules was an appeal for teachers so they can produce electronic teaching materials based on student's condition.
\end{abstract}

Keywords—school policies, learning activities, e-module

\section{INTRODUCTION}

The Covid-19 pandemic experienced by Indonesia and the world has changed the learning system. E-learning is the only solution for continuing to carry out learning activities. Elearning is a form of learning approach that is carried out virtual or online [1]. Many media can be used in e-learning, such as e-mail, blogs, Wikipedia, e-portfolios, animation, video links to social networks, such as Facebook, Twitter, YouTube, Google Classroom, Edmodo, and so on. E-learning is increasingly becoming an option because it saves time and is more flexible. E-learning development that is currently often used and is an option is to use the Web Course, Centric Course, and Web-Enhanced Course [2]. The variety of media choices should be utilized by both teachers and lecturers.

Covid-19 forces every activity to stop, one of which is teaching and learning activities in schools. Learning activities that initially took place face-to-face are now mostly done by learning online or online. Online learning chosen as an alternative to learning cannot be separated from our status which states that we are entering the industrial era 4.0. As stated by the Minister of Communication and Information, Jonnhy G. Plate, that we are entering the industrial era 4.0 at the signing of the MoU and PKS DTS 2020. Industry 4.0 forces us to adapt to rapid changes, where technology is more advanced than the previous era. This change in the way of learning from face-to-face to online or online was carried out as a government effort to reduce the number affected and to reduce the spread of the outbreak. These changes certainly affect the learning process and student learning. Besides, there may also be cultural lag as a result of these changes. The role of teachers at school had to be replaced by parents at home. Teachers no longer supervise students' learning directly and need parents to replace them. This means that there is a change in roles and functions as a result of changes in the way of learning from face-to-face to online

There are several classifications of the stages of using information technology in learning, namely emerging, applying, integrating, and transforming. Emerging is the initial stage of realizing the importance of technology for learning. Applying is the stage of applying technology as an object to be studied. Integrating is the process of integrating into the curriculum. Meanwhile, the fourth, transforming, is the most ideal stage, because information technology has become a catalyst for the evolution of education [3]

But, after the imposition of online or online learning through media that are considered easier for students to reach, it does not make this learning more or as effective as learning by teachers in schools. Face-to-face explanations are considered more understood by students than explanations via online media. Some teachers and students do not understand what and how to learn online. There is a mistake about online learning that should be done, the teacher gives a lot of tasks to students which makes students stressed at home. Different from the original goal, online learning should be a substitute for teaching and learning that cannot be done in the classroom. Therefore, a clear strategy needs to be considered so that educational problems at this time can be resolved. 
One school that has also felt the impact of the Covid-19 pandemic is SMK Negeri 2 Malang. SMK Negeri 2 Malang is one of the public SMKs in the city of Malang which is located on Jalan Veteran no.17 Malang and is directly opposite the main gate of Universitas Brawijaya. SMK Negeri 2 Malang has six skill competencies, namely Social Work, Tourism, Hospitality, Catering, Nursing, and Computer and Network Engineering. Until now, SMK Negeri 2 Malang has always made changes as an effort to adapt to the needs of the business world, industry, and the applicable curriculum. In order to cope with drastic changes in teaching methods, the principal formulated a policy. Therefore, this study aims to analyse school policies in learning activities during the Covid-19 pandemic.

The policy formulated by the principal is a concrete form of immediately adjusting to the very rapid changes in the Covid19 pandemic era. With the existence of policies issued by schools regarding the preparation of e-modules by teachers. Basically, there is no difference between the concept of a module and an electronic module or e-module. The only difference lies in the physical presence of the electronic module which requires a computer device to use it. E-modules can be developed using Moodle software. Moodle is the best LMS application in terms of features compared to other LMS types. In this study, Moodle serves as a forum for placing various course materials which will be packaged in a user-friendly appearance according to the needs of teachers and students [4].

Teachers should still need to convey material that should be accepted by students. If that is not possible, then one solution is to use a module that can be accessed by students online or called an e-module. e-module can be interpreted as an electronic module, non-printed and only in the form of files that can be opened with the help of electronic media such as tablets, smartphones, computers, and other electronic media based on operating systems, especially Android [5]. The components contained in the electronic module are also the same as the printed module including (1) learning objectives, (2) subject matter, (3) exercises to test the abilities of students after learning them, and (4) feedback which is an indicator of the achievement of learning outcomes done by students.

According to Riyadi [5], the preparation of e-modules should be carried out systematically, rationally, directed, and accompanied by instructions for use for lecturers or teachers. Thus the resulting e-module must: (1) be systematically designed and the material arranged according to the needs and characteristics of students, (2) Use simple and clear sentences so that they are easy to understand and have a level of difficulty that is adjusted to the knowledge of students, (3) ) emodule is designed to improve students' understanding of concepts in learning through message design (written or pictured), and (4) can be used for group learning.

This policy is related to all elements of school management, both in the fields of curriculum, facilities, and infrastructure, and teachers. The teacher is the spearhead of the implementation of learning both online and online. There are changes in the way teachers teach and learn should be motivated to make learning innovations, especially in online learning. School policies regarding e-modules also need to be facilitated by the school so that the preparation of e-modules can be realized according to needs. This is a challenge for the academic community of Brawijaya University. to develop research which later will be of benefit to other formal institutions outside of Brawijaya University, especially educational institutions.

\section{METHODS}

This research uses a qualitative approach, with a descriptive type of research. This study will describe how the results of the researcher's analysis of the policies issued by the principal. This research was conducted at SMK Negeri 2 Malang, which is addressed at Jalan Veteran No.17 Malang, East Java, Indonesia. Sampling using a purposive sampling technique using google form. The sampling technique used in this study was the purposive sampling technique. Data collection used a questionnaire given to 105 respondents, namely teachers of SMK Negeri 2 Malang.

\section{RESULTS}

SMK Negeri 2 Malang has three groups of teaching staff, namely the Normative teacher group, the Adaptive teacher group, and the Productive teacher group. The Normative teacher group consists of teachers of Religion subjects and teachers of Civic Education (Civics) subjects. The adaptive teacher group consists of teachers in Mathematics, Indonesian, English, Cultural Arts and Natural Sciences (IPA), Japanese, Entrepreneurship, and History / Social Sciences (IPS). While the productive teacher group is divided into six groups according to the field of expertise program or department at SMK Negeri 2 Malang. Six Productive teacher groups, namely the Social Work (PS) teacher group, the Tourism teacher group, the Hospitality teacher group, the Catering teacher group, the Nursing teacher group, and the Computer and Network Engineering teacher group.

The principal uses three stages to determine school policy. These stages are the formulation stage, the implementation stage, and the evaluation stage. At the formulation stage, the principal takes a policy based on the results of the study and discussion along with the curriculum and management time. The implementation of the principal's policy on e-module preparation by teachers is carried out in 4 stages, namely socialization, workshops, implementation, and evaluation Policy socialization is carried out during official meetings for all teachers. The workshop activities are carried out in two stages, namely a workshop on the preparation of e-modules and a workshop on the use of e-learning. Implementation of the policy starts in the odd semester of 2020/2021.

Based on the results of the questionnaire, information was obtained that $86 \%$ of teachers have never independently compiled modules. $80 \%$ of teachers use Whatsapp or Whatsapp groups for online learning, $17 \%$ of teachers have used class, the 
Learning Management System owned by SMK Negeri 2 Malang which is generally used as a medium for carrying out online exams. After the teachers participated in the module preparation workshop activities, $64 \%$ of the teachers still downloaded the online modules in pdf form and only $20 \%$ of the teachers wanted to compile the modules independently, $16 \%$ of the teachers joined the team that compiled the modules. During the new school year, only $20 \%$ of teachers uploaded self-made e-modules.

\section{DISCUSSION}

The principal's policy regarding the preparation of emodules by teachers goes through the planning or formula, implementation, and evaluation stages. This is following the stages of determining the policies conveyed by Putt and Springer [6] which states that there are three policy processes, namely, Formulation, Implementation, and Evaluation. In the formulation stage, the principal conducted a study based on the problems that existed at school, especially in service to students during the Covid-19 pandemic and the benefits obtained by both teachers, students, and the school. At this stage, the principal has considered that the policies to be taken should be especially beneficial for students [7].

The principal also conducted a study of the results of the study of problems experienced by students, namely 1) students found it difficult to obtain material as learning material during online learning, 2) The use of online learning applications by various teachers, namely $82 \%$ using WA groups to deliver assignments, $18 \%$ of assignments used class, $3 \%$ a combination of WA Group and class, 3) $80 \%$ of students complained about too many assignments given by the teacher. Problems found by school principals generally appear in almost every school, because the covid-19 pandemic has changed the way of learning and teaching, which was face-to-face, when the pandemic had to be done online [8]. Also, the overwhelming amount of work was very troubling for both students and parents. Even though students can do it by searching for answers from the internet, they still don't understand it [9]. Based on the problems experienced by students, the principal has a limited discussion with the vice principal in the fields of curriculum, facilities and infrastructure, student affairs, and public relations. The policy to be taken by the principal requires the role of the teacher, vice-principal, and school committee. Policies also need to be socialized to all elements in schools so that policy implementation has the support of all parties [10].

The second stage in the principal's policy is an implementation stage. The policy implementation stage is carried out in three stages, namely socialization, workshops, and implementation. The principal's policy outreach activities are aimed primarily at teachers because teachers have a direct role in learning, and teachers are directly related to this policy. The socialization was carried out directly by the school principal at Rapat Dinas attended by teachers and staff, held on June 15, 2020, to coincide with the end of the 2019/2020 school year. Even though it has been determined as a policy, the principal provides services so that the policy can be implemented properly, namely by holding workshops. There are 2 main workshops held, namely a workshop on e-module preparation and a workshop on the use of LMS e-learning at SMK Negeri 2 Malang. The workshop is one of the supporting activities for teachers to improve the quality of productivity that supports the policies of the school [11]. Policy implementation is carried out in the new academic year 2020/2021. Learning is carried out in full online using LMS elearning SMK Negeri 2 Malang.

The third stage in the principal's policy is evaluation. The evaluation of the implementation of the principal's policies aims to reveal how much the e-module preparation policies are implemented and used in online learning. Also, the evaluation aims to determine the effectiveness and efficiency of the policies that have been set [12]. Based on the results of the evaluation of school principals and school management, it is found that $100 \%$ of teachers have used LMS e-learning SMK Negeri 2 Malang for attendance activities, uploading materials, uploading assignments, quizzes, and exams. Meanwhile, the teacher needs to meet virtual eyes using the Google Meet or Zoom application. However, only $20 \%$ of teachers have uploaded e-modules that are purely teacher-made. While the rest uploaded the material in pdf format. Facts in the field are not as expected. The policy regarding the arrangement of emodules which is uploaded to the e-learning LMS of SMK Negeri 2 Malang is expected to be able to accommodate the module material which is packaged interactively so that students can learn independently. According to Sanova [13], learning activities using LMS can accommodate several materials with various features such as course content, such as module material which is packaged in interactive flash animation, assignments or exams, as well as instructional videos and structured assignments that can be used to measure student achievement.

\section{CONCLUSION}

The policies taken by the principal go through the planning, implementation, and evaluation stages. At the planning stage, the principal involved the management team of SMK Negeri 2 Malang, namely the deputy principal in the fields of curriculum, facilities, and infrastructure, public relations, and student affairs. Also, the determination of the policy plan is based on the results of the situation analysis that occurred at SMK Negeri 2 during online learning during the first lockdown, namely from March to June 2020. At the implementation stage, the principal determines the implementation of policies starting at the beginning of the new school year 2020/2021, namely implementation using LMS elearning SMK Negeri 2 Malang. The results of the evaluation show that only $20 \%$ of the teachers are ready to use the emodule. Meanwhile, other teachers only uploaded the material in pdf form to the LMS e-learning SMK Negeri 2 Malang. 


\section{ACKNOWLEDGMENT}

Thank you to SMK Negeri 2 Malang for permitting to conduct research. The vice-principal of public relations for his cooperation, as well as teachers who were willing to fill out the questionnaire.

\section{REFERENCES}

[1] M. Yaumi, "The Implementation Of Distance Learning In Indonesian Higher Education,” Lentera Pendidik. J. Ilmu Tarb. dan Kegur., vol. 10, no. 2, pp. 196-215, 2007.

[2] S.S. Noesgaard and R. Ørngreen, "The effectiveness of e-learning: An explorative and integrative review of the definitions, methodologies and factors that promote e-Learning effectiveness," Electron. J. e-Learning, vol. 13, no. 4, pp. 278-290, 2015.

[3] R.P. Yaniawati, "Using Mathematics Assessment Based on E-Learning To Improve Students ' Mathematical Power,' Int. J. Manag. Appl. Sci., vol. 2, no. 10, pp. 130-135, 2016.

[4] N. Sugihartini and N.L. Jayanta, "Pengembangan E-Modul Mata Kuliah Strategi Pembelajaran,” J. Pendidik. Teknol. dan Kejuru., vol. 14, no. 2, 2017.

[5] S. Riyadi, K. Qamar and I. Universitas Kanjuruhan Malang, Jawa Timur, "Efektivitas E-Modul Analisis Real Pada Program Studi Pendidikan Matematika Universitas Kanjuruhan Malang," Supremum J. Math. Educ. J., vol. 1, no. 1, pp. 26-33, 2017.
[6] S. Syafaruddin, Efektivitas kebijakan pendidikan: konsep, strategi dan aplikasi kebijakan menuju organisasi sekolah efektif. Rineka Cipta, 2008.

[7] A. Muhlis, "Kebijakan Pemerintah Dalam Pengembangan Kurikulum Dengan Model Sistem Kredit Semester Di Madrasah," TADRIS J. Pendidik. Islam, vol. 11, no. 1, p. 116, 2016.

[8] D.Y. Irawati and J. Jonatan, "Evaluasi Kualitas Pembelajaran Online Selama Pandemi Covid-19: Studi Kasus di Fakultas Teknik, Universitas Katolik Darma Cendika,” J. Rekayasa Sist. Ind., vol. 9, no. 2, pp. 135$144,2020$.

[9] M.E. Firmiana and S. Rahmawati, Meningkatkan keyakinan diri (selfefficacy) siswa di masa pembelajaran online selama pandemi covid-19, 2020.

[10] A.F.B. Adam, "Analisis Implementasi Kebijakan Kurikulum Berbasis Lingkungan Hidup pada Program Adiwiyata Mandiri di SDN Dinoyo 2 Malang," J. Kebijak. dan Pengemb. Pendidik., vol. 2, no. 2, pp. 166173, 2014.

[11] I. Gunawan, "Strategi Meningkatkan Kinerja Guru: Apa Program Yang Ditawarkan Oleh Kepala Sekolah,” Pros. Semin. Nas. Pengemb. Karir Tenaga Pendidik Berbas. Karya Ilm., vol. 23 Agustus, pp. 305-312., 2015 .

[12] A.R.M.A. Ramdhani, "Konsep Umum Pelaksanaan Kebijakan Publik," J. Publik, vol. Vol 11, no. January, pp. 1-12, 2016.

[13] A. Sanova, “Aplikasi Learning Management System (LMS) pada Pengembangan Modul Elektronik Materi Atmosfer Bumi Menggunakan 3D Pageflip Professional," J. Indones. Soc. Integr. Chem., vol. 10, no. 2, pp. 1-13, 2019. 